\title{
Epidemiological analysis of nifedipine and phenytoin-induced gingival overgrowth in users of the Primary Health Care System
}

\author{
Análise epidemiológica do aumento gengival induzido por \\ nifedipina e fenitoína em usuários da Atenção Primária à Saúde
}

\begin{abstract}
Purposes: The aim of this study was to evaluate the prevalence of drug-induced gingival overgrowth (DIGO) in Brazilian users of nifedipine and/or phenytoin and to determine the presence of predisposing/modifying factors.

Methods: Demographic, pharmacological, and periodontal data were obtained from 100 users of the Brazilian Primary Health Care System in Diamantina, Jequitinhonha Valley, Minas Gerais state, Brazil, who were taking nifedipine and/or phenytoin. Clinical evaluations including gingival overgrowth analysis were carried out by a single calibrated examiner. Bivariate analysis (Chi-square test or Student's t-test) were used to identify demographic, periodontal and drugrelated significant factors associated with gingival overgrowth severity. Multivariate analysis (Poisson regression) was used to assess confounding factors.

Results: The prevalence of DIGO was high (86\%), but its severity was predominately mild. The prevalence of DIGO was significantly higher in phenytoin users than in nifedipine users $(P=0.01)$. There was no association between DIGO and demographic, pharmacological or periodontal variables.

Conclusion: The high occurrence of DIGO among users of nifedipine and phenytoin emphasizes the importance of the dentist as part of the public health team to provide the prevention, early diagnostic, and control of this alteration.
\end{abstract}

Key words: Nifedipine; phenytoin; gingival overgrowth; primary health care

\section{Resumo}

Objetivo: Avaliar a prevalência dos aumentos gengivais medicamentosos em usuários brasileiros de nifedipina e fenitoína e determinar a presença de fatores preditores/modificadores.

Metodologia: Dados demográficos, farmacológicos e periodontais foram obtidos de 100 pacientes usuários da Atenção Primária no Vale do Jequitinhonha que usavam nifedipina e/ou fenitoína. Avaliações clínicas, incluindo a análise do aumento gengival, foram feitas por um avaliador calibrado. Análises bivariadas (teste do qui-quadrado ou teste t de Student) foram usadas para identificar fatores demográficos, periodontais e medicamentosos que apresentassem associação com a severidade do aumento gengival. Foi utilizada análise multivariada (regressão de Poisson) para estimar a razão de prevalência e intervalo de $95 \%$ de confiança para identificar os fatores de risco associados ao desenvolvimento do AG.

Resultados: A prevalência do aumento gengival foi elevada (86\%), mas a gravidade mais comumente observada foi a leve. A prevalência foi maior em usuários de fenitoína do que de nifedipina $(P=0.01)$. Não houve associação entre aumento gengival e as variáveis demográficas, farmacológicas e periodontais.

Conclusão: A alta prevalência do aumento gengival medicamentoso entre os usuários de nifedipina e fenitoína enfatiza a importância do cirurgião dentista no diagnóstico, prevenção e controle dessa alteração.

Palavras-chave: Nifedipina; fenitoína; hiperplasia gengival; atenção primária em saúde

\author{
Luciara Viana Leão Fonseca a \\ Hercílio Martelli Júnior b \\ Patrícia Furtado Gonçalves a \\ Fillipe Mateus Castro de Carvalho a \\ Ricardo Della Coletta c \\ Paulo Rogério Ferreti Bonan b
}

\begin{abstract}
- Department of Dentistry, Federal University of Jequitinhonha and Mucuri Valleys, Diamantina, MG, Brazil

b Department of Dentistry, State University of Montes Claros, Montes Claros, MG, Brazil

c Department of Dentistry, State University of Campinas, Piracicaba, SP, Brazil
\end{abstract}

\author{
Correspondence: \\ Luciara Leão Viana Fonseca \\ Rua da Glória, 187, Centro \\ Diamantina, MG - Brasil \\ 39100-000 \\ E-mail: luciaraleao@hotmail.com
}

Received: January 29, 2010

Accepted: April 9, 2010

Conflict of Interest Statement: The authors state that there are no financial and personal conflicts of interest that could have inappropriately influenced their work.

Copyright: (c) 2010 Fonseca et al.; licensee EDIPUCRS. This is an Open Access article distributed under the terms of the Creative Commons AttributionNoncommercial-No Derivative Works 3.0 Unported License. 


\section{Introduction}

Several systemic diseases and medications used to treat these conditions may influence oral health status (1). Drug-induced gingival overgrowth (DIGO) is the main side effect in the oral cavity among users of nifedipine, a beta-blocker of calcium channels, and phenytoin, an anti-seizure drug $(2,3)$. DIGO frequently begins during the first 3 months after medication, with variable extent, from small alterations in the gingival papilla to total coverage of the dental crown. It is more conspicuous in the buccal than in the lingual gingiva and less severe in the maxilla than in the mandible $(4,5)$. DIGO may lead to esthetic and/or functional alterations, impairing occlusion, mastication and speech $(2,6)$. It also impairs dental hygiene, resulting in a higher susceptibility to caries and periodontal diseases (6). The prevalence of this DIGO is widely variable (2), but large controlled studies have revealed a percentage of $50 \%$ for phenytoin users, and 6 to $83 \%$ for nifedipine users $(2,7)$. Furthermore, several factors, including age, genetic predisposition, pharmacokinetic variables, dental biofilm accumulation and drug-induced activation of cytokines have been suggested to influence the development of DIGO (8).

There is a substantial knowledge about the clinical features of DIGO; however, there is a paucity of epidemiological studies involving DIGO in the Brazilian population. The Brazilian Primary Health Care System service represents the patient's first contact with the health public care system, and is especially responsible for the attendance of patients with chronic diseases. The Brazilian Primary Health Care System also provides pharmaceutical assistance to low income patients, offering indispensable drugs to control chronic diseases, including nifedipine and phenytoin (9). The aim of this study was to evaluate the prevalence of DIGO among Brazilian patients who were prescribed nifedipine or phenytoin through the program of pharmaceutical assistance of the Brazilian Primary Health Care System, and to comprehend its clinical characteristics and risk factors.

\section{Methodology}

This descriptive and cross-sectional study was conducted across the population basis, according to ethical principles in human research and was approved by the Ethical Committee of State University of Montes Claros (678/2007). This survey was conducted in Diamantina, a municipality in the Jequitinhonha Valley of the Brazilian State of Minas Gerais, one of the poorest regions in Brazil (total population of 44,746) (21). Using the records of the Brazilian Primary Health Care System, the initial number of patients listed for participation in the study was 395 individuals. However, losses occurred due to factors such as missing address, migration, death and drug discontinuity (112 patients were totally edentulous, 37 had interrupted the use of the drugs, 21 had already died, 13 patients refused to participate, 27 had moved to another city and 85 were not found at the registered addresses).
Thus, a total of one hundred patients (62 nifedipine users, 37 pheynitoin users and one user of both nifedipine and phenythoin) comprised this analysis. Exclusion criteria included patients aged less than eleven years, and patients who referred irregular utilization or less than three months of drug initiation. Patients presenting less than four anterior inferior or superior teeth and co-users of other drugs that result in gingival overgrowth were also excluded.

Patients were contacted at their homes and invited to participate in the study. Those who agreed to participate signed a consent form and responded to an interview conducted by one previously trained investigator. After the interview, the researcher-examiner held the clinical intra-oral examination. All patients were examined with appropriate instruments (periodontal probe, clinical mirror and wooden spatula), in ideal conditions of biosecurity and under artificial lighting.

Demographic data, including gender, age, profession, monthly income, scholarship level, complete medical history including past and actual diseases, drugs, concentrations, posology and time of treatment were considered and listed for each patient, through individual interviews (questionnaire). Patients were asked about their perception of any change in their gums, and if so were asked if they sought professional assistance for the problem.

\section{Gingival and Periodontal Conditions}

The gingival and periodontal conditions were accessed by a single-blinded examiner (intra-examiner agreement tested by means of Kappa test, Kappa $=0.85$ ). Gingival overgrowth and dental biofilm evaluation was performed and restricted to twelve anterior/superior teeth. The following parameters were used:

1. Index to evaluate the periodontal condition-Community Periodontal Index (CPI), $(20,26)$ according to the criteria established in the $4^{\text {th }}$ edition of the Basic Survey of Oral Health of the World Health Organization and in a national oral health survey (SB Brasil) conducted in 2002-2003 by the Brazilian Health Ministry.

2. Plaque Index (13) - Evaluated the presence/absence of biofilm by the dual count. After the calculated count for each patient, the percentage of teeth with biofilm was categorized on a scale of four points.

3. Gingival Overgrowth Index (10) - The gingival overgrowth was evaluated clinically in each patient using a scale of four points $(0=$ without overgrowth, $1=$ mild overgrowth without dental crown involvement, $2=$ moderate overgrowth with increased interdental papilla and slight increase over the dental crown, $3=$ evident overgrowth involving the crown surface). In the absence of teeth, the adjacent dental papilla of the edentulous area was considered in the classification. The patient's score for tthis index was considered as the most prevalent in percentage. For the patients with grades 2 (moderate) or 3 (severe overgrowth), surgical therapies were carried out. All patients were instructed about oral hygiene and received professional dental cleaning. 


\section{Statistical Analysis}

Plaque índex, CPI and Gingival overgrowth index were calculated for each patient. The normality of the distribution of these variables was tested thought the one-sample Kolmogorov-Sminorv test and was confirmed as normal. The Gingival overgrowth index was re-categorized in presence or absence. Chi-square test and Student t-test were used to identify the association between DIGO with demographic, periodontal and pharmacological features, thought a bivariate analysis. Multivariate analysis through the Poisson Regression was conducted to verify the DIGO associated risk factors. A 5\% significance level was settled for all statistical analyses $(P<0.05)$, except for the bivariate analysis $(\alpha=25 \%)$.

\section{Results}

\section{Demographic and medical variables}

Among the 100 individuals, the age ranged from 11 to 81 years (mean age of $46.8 \pm 15.1$ ). Melanoderm individuals were more prevalent $(44(44 \%))$. Due to a wide variation of professions that were referred to, these professions were categorized and the most common was identified as manual work (60\%). Of all analyzed patients, $61 \%$ had not concluded basic education. A family income of less than the minimum wage was cited by the majority (67\%). The most important demographic data are listed in Table 1.

With regard to the medical history of these individuals, the most prevalent diseases were arterial hypertension (63\%), followed by neuropsychiatry disturbances $(28 \%)$. The majority of individuals were under medical follow up (82\%), and utilized the SUS units (67\%). The other 33\% utilized, simultaneously, private health units.

\section{Phamacological Variables}

Nifedipine users comprised $62 \%$ of the evaluated sample, followed by phenytoin users (37\%) and one patient used both medications. Only 5 individuals (5\%) had been using these drugs for three months to one year, 29 (29\%) for one year to three years and $65 \%$ for more than three years. Demographic data and drug utilization are shown in Table 2.

\section{Periodontal Variables}

Gingival overgrowth was considered mild in 54(54\%) individuals, moderate in $30(30 \%)$ and severe in $2(2 \%)$. Although the prevalence of DIGO in both groups reached $86 \%(P=0.01), 71$ individuals $(71 \%)$ did not perceive any gingival alterations. Of the individuals who perceived the DIGO, 15 (51.72\%) did not seek dental care.

Considering the groups alone, the prevalence of DIGO associated with nifedipine was $79 \%$ among users of this drug and $97.3 \%$ among the users of phenytoin. The mild DIGO was more prevalent in both groups [nifedipine $(51.6 \%)$ and phenytoin $(56.8 \%)]$. The majority presented an elevated level of dental plaque ( 76 to $100 \%$ of examined teeth), $61.2 \%$ being nifedipine users and $54 \%$ phenytoin users. Regarding the periodontal condition of these individuals, periodontal pockets of 4 to $5 \mathrm{~mm}$ and dental calculus were largely found in both groups. The periodontal condition data are presented in Table 3.

Table 1. Distribution of individuals in treatment with phenynoin or/and nifedipine, according to general demographic data $(n=100)$.

\begin{tabular}{llcc}
\hline \multicolumn{1}{c}{ Variable } & \multicolumn{1}{c}{ Category } & $\mathbf{n}$ & $\%$ \\
\hline Gender & Male & 49 & 49 \\
& Female & 51 & 51 \\
& Melanoderm & 44 & 44 \\
& Feoderm & 43 & 43 \\
& Leucoderm & 13 & 13 \\
Profession & Retired, without defined & 25 & 25 \\
& profession, or student & & \\
& Manual job & 60 & 60 \\
Schooling & Non-manual job & 15 & 15 \\
Level & Illiterate & 8 & 8 \\
& $1^{\text {st }}$ grade incomplete & 61 & 61 \\
& $1^{\text {st }}$ grade complete & 15 & 15 \\
& $2^{\text {nd }}$ gradecomplete & 13 & 13 \\
Monthly Family & Up to one minimum wage & 3 & 3 \\
Income & One to two minimum wages & 22 & 22 \\
& More than two minimum wages & 11 & 11 \\
\hline
\end{tabular}

Table 2. Distribution of patients, according to demographic and pharmacological variables $(n=100)$

\begin{tabular}{|c|c|c|c|c|c|c|}
\hline & \multicolumn{2}{|c|}{ Nifedipine } & \multicolumn{2}{|c|}{ Phenytoin } & \multicolumn{2}{|c|}{$\begin{array}{l}\text { Nifedipine and } \\
\text { Phenytoin }\end{array}$} \\
\hline & $\mathrm{n}$ & $\%$ & $\mathrm{n}$ & $\%$ & $\mathrm{n}$ & $\%$ \\
\hline $\begin{array}{l}\text { Number of patients } \\
\text { Males } \\
\text { Females }\end{array}$ & $\begin{array}{l}62 \\
30 \\
32\end{array}$ & $\begin{array}{l}62 \\
30 \\
32\end{array}$ & $\begin{array}{l}37 \\
18 \\
19\end{array}$ & $\begin{array}{l}37 \\
18 \\
19\end{array}$ & 0 & 01 \\
\hline Mean age (years) & \multicolumn{2}{|c|}{53} & \multicolumn{2}{|c|}{37} & & \\
\hline Variation (min - max) & \multicolumn{2}{|c|}{$(27-76)$} & \multicolumn{2}{|c|}{$(11-81)$} & & \\
\hline Standard doses & \multicolumn{2}{|c|}{$30-60 \mathrm{mg} / \mathrm{day}$} & \multicolumn{2}{|c|}{$100-300 \mathrm{mg} /$ day } & & \\
\hline Mean doses & \multicolumn{2}{|c|}{$41 \mathrm{mg} /$ day } & \multicolumn{2}{|c|}{$180 \mathrm{mg} /$ day } & & \\
\hline Variation (min-max) & \multicolumn{2}{|c|}{ (20-100 mg/day) } & \multicolumn{2}{|c|}{ (25-400 mg/day) } & & \\
\hline Time of utilization (months-mean) & \multicolumn{2}{|c|}{68} & \multicolumn{2}{|c|}{129} & & \\
\hline Variation (min-max) & \multicolumn{2}{|c|}{$(12-240)$} & \multicolumn{2}{|c|}{$(4-516)$} & & \\
\hline
\end{tabular}


The bivariate analysis identified monthly family income ( $P=0.04)$, source of medication $(P=0.01)$, the drug concentration $(P=0.022)$ and treatment duration $(P=0.194)$ as predictor factors associated with gingival overgrowth
(Table 4). Nevertheless, after multivariate analysis, only the source of medication, specifically phenytoin, presented significant association with gingival overgrowth $(P=0.007)$ (Table 5).
Table 3. Distribution of patients, according to periodontal variables observed.

Table 4. Bivariate analysis $(\alpha=25 \%)$ performed to verify the association between GO, demographic, drugs, and periodontal features in users of nifedipine or phenytoin $(n=100)$.

Table 5. Multivariate analysis (Regression of Poisson - RP) to verify the association between $\mathrm{GO}$, demographic and drug features in users of nifedipine or phenytoin $(n=100)$.

\begin{tabular}{|c|c|c|c|c|c|}
\hline \multirow{2}{*}{$\begin{array}{c}\text { Variable } \\
\text { Gingival Overgrowth }\end{array}$} & \multirow{2}{*}{$\begin{array}{l}\text { Category } \\
\text { Absent }\end{array}$} & \multicolumn{2}{|c|}{$\begin{array}{c}\text { Nifedipine } \\
\mathrm{n}=62 / \mathrm{n} \%\end{array}$} & \multicolumn{2}{|c|}{$\begin{array}{l}\text { Phenytoin } \\
\mathrm{n}=37 / \mathrm{n} \%\end{array}$} \\
\hline & & 13 & 21 & 1 & 2.7 \\
\hline & Mild & 32 & 51.6 & 21 & 56.8 \\
\hline & Moderate & 16 & 25.8 & 14 & 37.8 \\
\hline & Severe & 1 & 1.6 & 1 & 2.7 \\
\hline \multirow[t]{3}{*}{ Plaque Index } & 0 to $50 \%$ & 12 & 19.4 & 7 & 19 \\
\hline & 51 to $75 \%$ & 12 & 19.4 & 10 & 27 \\
\hline & 76 to $100 \%$ & 38 & 61.2 & 20 & 54 \\
\hline \multirow[t]{5}{*}{$\mathrm{CPI}$} & Health & 5 & 8.1 & 3 & 8.1 \\
\hline & Bleeding & 8 & 12.9 & 3 & 8.1 \\
\hline & Calculus & 26 & 41.9 & 13 & 35.1 \\
\hline & Pockets of $4-5 \mathrm{~mm}$ & 17 & 27.4 & 13 & 35.1 \\
\hline & Pockets over $6 \mathrm{~mm}$ & 6 & 9.7 & 5 & 13.5 \\
\hline
\end{tabular}

\begin{tabular}{|c|c|c|c|}
\hline Variable & Without overgrowth & With overgrowth & $\mathrm{P}$ \\
\hline Age & $51.4 \pm 3.6$ & $46.12 \pm 1.6$ & $0.23^{*}$ \\
\hline $\begin{array}{l}\text { Gender } \\
\text { Male (\%) } \\
\text { Female (\%) }\end{array}$ & $\begin{array}{l}7 \\
7\end{array}$ & $\begin{array}{l}42 \\
44\end{array}$ & 0.94 \\
\hline $\begin{array}{l}\text { Family Income } \\
\text { Up to one minimum wage (\%) } \\
\text { More than one minimum wage(\%) }\end{array}$ & $\begin{array}{l}6 \\
8\end{array}$ & $\begin{array}{l}60 \\
25\end{array}$ & $0.041^{*}$ \\
\hline $\begin{array}{l}\text { Profession } \\
\text { Without occupation or retired (\%) } \\
\text { Professionally active (\%) }\end{array}$ & $\begin{array}{c}2 \\
12\end{array}$ & $\begin{array}{l}22 \\
63\end{array}$ & 0.34 \\
\hline $\begin{array}{l}\text { Schooling } \\
\text { Illiterate (\%) } \\
\text { Non Illiterate (\%) }\end{array}$ & $\begin{array}{c}1 \\
13\end{array}$ & $\begin{array}{c}7 \\
79\end{array}$ & 0.89 \\
\hline $\begin{array}{l}\text { Type of drug } \\
\text { Nifedipine (\%) } \\
\text { Phenytoin (\%) } \\
\text { Both }\end{array}$ & $\begin{array}{c}13 \\
1 \\
0\end{array}$ & $\begin{array}{l}49 \\
36 \\
1\end{array}$ & $0.01^{*}$ \\
\hline $\begin{array}{l}\text { Concentration } \\
\text { Nifedipine Pattern } \\
\text { Phenytoin Pattern } \\
\text { Over than Nifedipine Pattern }\end{array}$ & $\begin{array}{c}12 \\
1 \\
1\end{array}$ & $\begin{array}{c}40 \\
37 \\
8\end{array}$ & $0.022^{*}$ \\
\hline $\begin{array}{l}\text { Doses } \\
\text { Low } \\
\text { Medium } \\
\text { High }\end{array}$ & $\begin{array}{c}3 \\
10 \\
1\end{array}$ & $\begin{array}{l}21 \\
48 \\
16\end{array}$ & 0.48 \\
\hline $\begin{array}{l}\text { Time of treatment } \\
\text { Up to three years } \\
\text { Over three years }\end{array}$ & $\begin{array}{l}7 \\
7\end{array}$ & $\begin{array}{l}27 \\
57\end{array}$ & $0.194^{*}$ \\
\hline $\begin{array}{l}\text { Plaque Index } \\
0 \text { to } 50 \% \\
51 \text { to } 75 \% \\
76 \text { to } 100 \%\end{array}$ & $\begin{array}{l}3 \\
4 \\
7\end{array}$ & $\begin{array}{l}16 \\
18 \\
52\end{array}$ & 0.74 \\
\hline $\begin{array}{l}\text { CPI } \\
\text { Without alteration } \\
\text { Calculus and bleeding } \\
\text { Periodontal Pockets } \\
\end{array}$ & $\begin{array}{l}1 \\
8 \\
5\end{array}$ & $\begin{array}{l}7 \\
42 \\
36\end{array}$ & 0.866 \\
\hline
\end{tabular}

\begin{tabular}{|c|c|c|c|}
\hline Variable & Category & $\operatorname{RP}(\alpha=5 \%)$ & $\mathrm{P}$ \\
\hline Income & $\begin{array}{l}\text { Up to one minimum wage } \\
\text { More than one minimum wage }\end{array}$ & $\begin{array}{c}1.15(0.94-1.40) \\
1.00\end{array}$ & 0.156 \\
\hline Drug & $\begin{array}{l}\text { Phenytoin } \\
\text { Nifedipine }\end{array}$ & $\begin{array}{c}1.22(1.06-1.42) \\
1.00\end{array}$ & $0.007^{*}$ \\
\hline Concentration & $\begin{array}{l}\text { Pattern } \\
\text { Over the pattern }\end{array}$ & $\begin{array}{c}0.92(0.70-1.21) \\
1.00\end{array}$ & 0.547 \\
\hline Time of utilization & $\begin{array}{l}\text { Up to three years } \\
\text { More than three years }\end{array}$ & $\begin{array}{c}0.88(0.74-1.05) \\
1.00\end{array}$ & 0.160 \\
\hline
\end{tabular}

* Statistically significant. 


\section{Discussion}

Calcium antagonists, such as nifedipine, are widely employed for the treatment of cardiovascular diseases or in patients submitted to dyalisis $(11,12)$. The most important secondary side effects of this drug are hypotension, headaches, flushness, dizziness, tremor, joint stiffness, peripheral edema, dermatitis, pruritis and urticaria (4). Besides these effects, DIGO is also related (12). Phenytoin (5-diphenilphenytoin) has been used to control seizure crisis in patients since its clinical introduction by Merritt \& Putnam in 1938 (5). DIGO is a frequent side effect in users of this drug (14).

The population of this study was comprised of individuals with low schooling level and reduced family income, compatible with the profile of the population assisted by the Brazilian Primary Health Care System (15). In contrast with the majority of studies that deal with DIGO, where the studied population is selected in medical or dentistry centers, this study aimed to characterize, epidemiologically and demographically, the local population receiving nifedipine and/or phenytoin (10, 16-19). As a result, this study presented some particularities such as the reduced number of teeth as inclusion criteria, due to the high grade of edentulism in the adult and elderly Brazilian population, the predominant sample of this study (20). In addition, a high level of dental biofilm was observed in the majority of evaluated individuals, in their residences. When the dental exam is previously scheduled, the scores of dental biofilm may be lower, due to more careful oral hygiene than under normal circumstances (11).

In this study, a high prevalence of DIGO was observed associated with nifedipine (79\%) and phenytoin (97.3\%), with a predominance of mild DIGO. This result surpasses the mean DIGO incidence, as related in the literature for phenytoin $(50 \%)$ and nipedipine $(0.5$ to $83 \%)(2,7,11,16,18)$. The large variation in the prevalence of DIGO in these studies may be due to variations in population characteristics, size sample, sample selection and methods employed to perform DIGO evaluation $(5,16)$.

No significant relationship was found between DIGO and demographic features such as age, gender, scholarship level, or profession, after the adjustment to determine the risk potential. Regarding income, all the populations in this study can be considered to be homogeneous, reflecting the situation of the majority of the population of this region. In Brazil, individuals that work in manual jobs are more likely to receive lower salaries than those that work in commerce or education, for example. This fact may have attenuated the strength of the association between income and the parameters measured in the present study.

Generally, there was no correlation of DIGO with race, gender and age, as demonstrated by previous studies, although this fact is not consensual $(2,14,24)$. In addition, the association between DIGO and pharmacological variables such as dose, concentration and time of treatment was not observed, in agreement with previous studies $(11,16,24,25)$. The attempt to associate doses, plasma and salivary levels, drug combinations, time of utilization with beta-blockers and phenytoin DIGO has presented contradictory results $(2,5)$. It is believed that there is a minimum level of drugs necessary to lead to DIGO. This level may differ depending on the responsiveness of the patient (5).

There are many reports of significant correlations between the presence and severity of DIGO induced by drugs and presence of biofilm, calculus, periodontal pockets, and the need for periodontal treatment and poor oral care $(16,18)$. The bacterial dental biofilm level is strongly associated with gingival and periodontal disease and its control has an important role in the control and prevention of DIGO $(5,6)$. Nevertheless, even in the presence of the high biofilm levels and CPI shown in this study, there was a lack of evidence of any association of these factors with DIGO, as demonstrated by other studies $(11,25)$. In addition, while there is evidence of the relationship between plaque-induced inflammation and DIGO, the role of dental biofilm may only be to enhance the effects of this gingival alteration, as proposed previously (10). Despite the controversy results of the relation between periodontal variables and DIGO, the role of the dental professional is still important to perform early diagnostic and control of this alteration.

Even with a large prevalence of DIGO in the studied population, the majority did not perceive any gingival alteration. This may be due to the fact that mild or moderate overgrowth was more frequently found, not affecting the esthetics or function in these patients. Nevertheless, even among patients who perceived the presence of DIGO, less than half sought professional dental care.

Considering the high prevalence of DIGO, induced by nifedipine and phenytoin, as pointed out in this study, and the fact that these drugs are widely employed to treat cardiovascular and neurological illness, the role of dental professionals in the Primary Health Care System is very important. These professionals must be stimulated to carefully review the medical history of patients using (or that have used) drugs with DIGO-inducing potential. In addition, a detailed oral examination is imperative to observe the morphological alterations associated with these drugs (5). In a recent study, it was demonstrated that the inclusion of an evaluation of oral health for patients assisted by preventive medical programs is an important strategy to target those at a risk of oral disease, taking into account the low perceptive capacity for dental care and irregular visiting patterns that many people present (22). Moreover, the literature also reports evidence of association between oral health status and affects the general quality of life (23).

In summary, within the limits of the present study, it is possible to conclude that nifedipine- and phenytoin-induced GO prevalence is high among users of Primary Health Care System. However, this alteration is more associated with phenytoin. Demographic, pharmacological, and periodontal features did not influence DIGO in the observed population. The high prevalence of DIGO in phenytoin and nifedipine users emphasizes the importance of the dental professional in the diagnosis, control and treatment of this important side effect, mainly in the Primary Care Health System. 


\section{Acknowledgments}

This study received financial support from FAPEMIG Foundation of Research Support of Minas Gerais State, Brazil.

\section{References}

1. Gallarreta FWM, Turssi CP, Palma-Dibb RG, Serra MC. Histórico de saúde: atenção a condições sistêmicas e suas implicações, sobretudo nos fatores de risco de cárie. Rev Odonto Ciênc 2008;23:192-6.

2. Seymour RA, Ellis JS, Thomason JM. Risk factors for drug-induced gingival overgrowth. J Clin Periodontol 2000;27:217-23.

3. Mavrogiannis M, Ellis JS, Thomason JM, Seymour RA. The management of druginduced gingival overgrowth. J Clin Periodontol 2006;33:434-9

4. Farias BC, Cabral PA, Gusmão ES, Jamelli SR, Cimões R. Nonsurgical treatment of gingival overgrowth induced by nifedipine: a case report on an elderly patient. Gerodontology 2010;27:76-80.

5. Hallmon WW, Rossmann JA. The role of drugs in the pathogenesis of gingival overgrowth. A collective review of current concepts. Periodontol 2000 1999;21:176-96.

6. Reali L, Zuliani E, Gabutti L, Schönholzer C, Marone C. Poor oral hygiene enhances gingival overgrowth caused by calcineurin inhibitors. J Clin Pharm Ther 2009;34:255-60.

7. Kataoka M, Kido J, Shinohara Y. Drug-induced gingival overgrowth-a review. Biol Pharm Bull 2005;28:1817-21.

8. Seymour RA, Thomason JM, Ellis JS. The pathogenesis of druginduced gingival overgrowth. J Clin Periodontol 1996;23:165-75.

9. Brasil. Ministério da Saúde. Secretaria de Ciência Tecnologia e Insumos. Departamento de Assistência Farmacêutica. Relação Nacional de Medicamentos Essenciais - RENAME. Brasília (DF): Ministério da Saúde; 2008.

10. Ellis JS, Seymour RA, Steele JG, Robertson P, Butler TJ, Thomason JM. Prevalence of gingival overgrowth induced by calcium channel blockers: a community-based study. J Periodontol 1999;70:63-7.

11. Barclay S, Thomason JM, Idle JR, Seymour RA. The incidence and severity of nifedipine-induced gingival overgrowth. J Clin Periodontol 1992; 19:311-4.

12. Shouda J, Nakamoto H, Sugahara S, Okada H, Suzuki H. Incidence of gingival hyperplasia caused by calcium antagonists in continuous ambulatory peritoneal dialysis patients. Adv Perit Dial 1999; 15:153-5.

13. Ainamo J, Bay I. Problems and proposals for recording gingivitis and plaque. Int Dent J 1975;25:229-35.

14. Guimarães-Júnior J. Hiperplasia gengival medicamentosa - parte I. J Epilepsy Clin Neurophysiol 2007;13:33-6.
15. IBGE - Instituto Brasileiro de Geografia e Estatística. Pesquisa Nacional por Amostra de Domicílios: acesso e utilização de Serviços de Saúde - 2003. Rio de Janeiro; 2005.

16. Neumann C, Willershausen-Zonnchen B, Klug C, Darius H. Clinical assessment of periodontal conditions in patients treated with nifedipine. Eur J Med Res 1996;1:273-9.

17. O'Valle F, Mesa F, Aneiros J, Gómez-Morales M, Lucena MA, Ramirez C, Revelles F, Moreno E, Navarro N, Caballero T et al. Gingival overgrowth induced by nifedipine and cyclosporin A. Clinical and morphometric study with image analysis. J Clin Periodontol 1995;22:591-7.

18. Miranda J, Brunet L, Roset P, Berini L, Farre M, Mendieta C. Prevalence and risk of gingival enlargement in patients treated with nifedipine. J Periodontol 2001;72:605-11

19. Majola MP, McFadyen ML, Connolly C, Nair YP, Govender M, Laher MHE. Factors influencing phenytoin-induced gingival enlargement. J Clin Periodontol 2000;27:506-12.

20. Brasil. Ministério da Saúde. Projeto SB Brasil 2003: condições de saúde bucal da população brasileira 2002-2003: resultados principais. Brasilia: Departamento de Atenção Básica, Coordenação Nacional de Saúde Bucal; 2004.

21. IBGE - Instituto Brasileiro de Geografia e Estatíestica. Cidades@ [cited on 2008 Nov 3]. Avaliable at: http://www.ibge.gov.br/ cidadesat/topwindow.htm? 1

22. Lowe C, Blinkhorn AS, Worthington HV, Craven R. Testing the effect of including oral health in general health checks for elderly patients in medical practice - a randomized controlled trial. Community Dent Oral Epidemiol 2007;35:12-7

23. Hugo FN, Hilgert JB, da Luz Rosário de Sousa M, Cury JA. Oral status and its association with general quality of life in older independent-living south-Brazilians. Community Dent Oral Epidemiol 2009;37:231-40.

24. Güncü GN, Çaglayan F, Dinçel A, Bozkurt A, Özmen F, Karabulut E. Clinical and pharmacological variables as a risk factor for nifedipineinduced gingival overgrowth. Aust Dent J 2007;52:295-9.

25. Brunet L, Miranda J, Roset P, Berini L, Farré M, Mendieta C. Prevalence and risk of gingival enlargement in patients treated with anticonvulsant drugs. Eur J Clin Invest 2001;31:781-8.

26. Organização Mundial de Saúde. Levantamentos Básicos em Saúde Bucal. $4^{a}$ ed. São Paulo: Livraria Santos Editora; 1999. 